\title{
МІЖНАРОДНИЙ ФОРУМ ЧЖУНГУАНЬЦУНЬ «НАУКОВІ Й ТЕХНОЛОГІЧНІ ІННОВАЦІЇ ТА СПІВПРАЦЯ МІЖ СВІТОВИМИ АКАДЕМІКАМИ»
}

\author{
16-18 жовтня 2019 р., м. Пекін, Китайська Народна Республіка \\ https://doi.org/10.37472/2707-305X-2019-1-1-3-4
}

Столиця Китайської Народної Республіки Пекін нині є величезним діловим мегаполісом, де спостерігається бурхливе зростання і розвиток усіх галузей економіки і науки. Чжунгуаньцунь технологічний і науковий центр Пекіна, розташований в районі Хайдянь, що на північному заході Пекіна, вважається свого роду китайською «Силіконовою долиною». Заснований цей центр у 1950-х рр. $з$ метою інтеграції наук та освіти. Наукові базу допомагають забезпечити близько 200 розташованих в Чжунгуаньцунь науководослідницьких інститутів. Це місце, де концентрується вся наукова спільнота країни, розташована Академія наук Китаю, Пекінський університет, інститут Цінхуа. А також тут розміщені центри міжнародних компанії: Nokia, Microsoft, IBM, Intel та інших.

Форум Чжунгуаньцунь був заснований у 2007 р., а тема «Інновації та розвиток» $€$ постійним напрямом, навколо якого концентруються такі глобально актуальні теми, як нові тенденції інноваційних кордонів і нові можливості для розвитку промисловості.

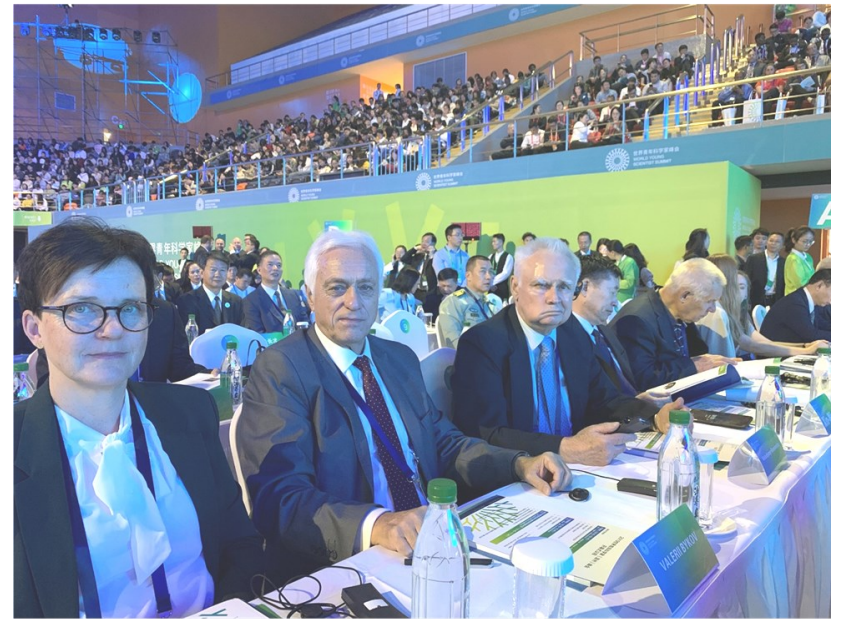

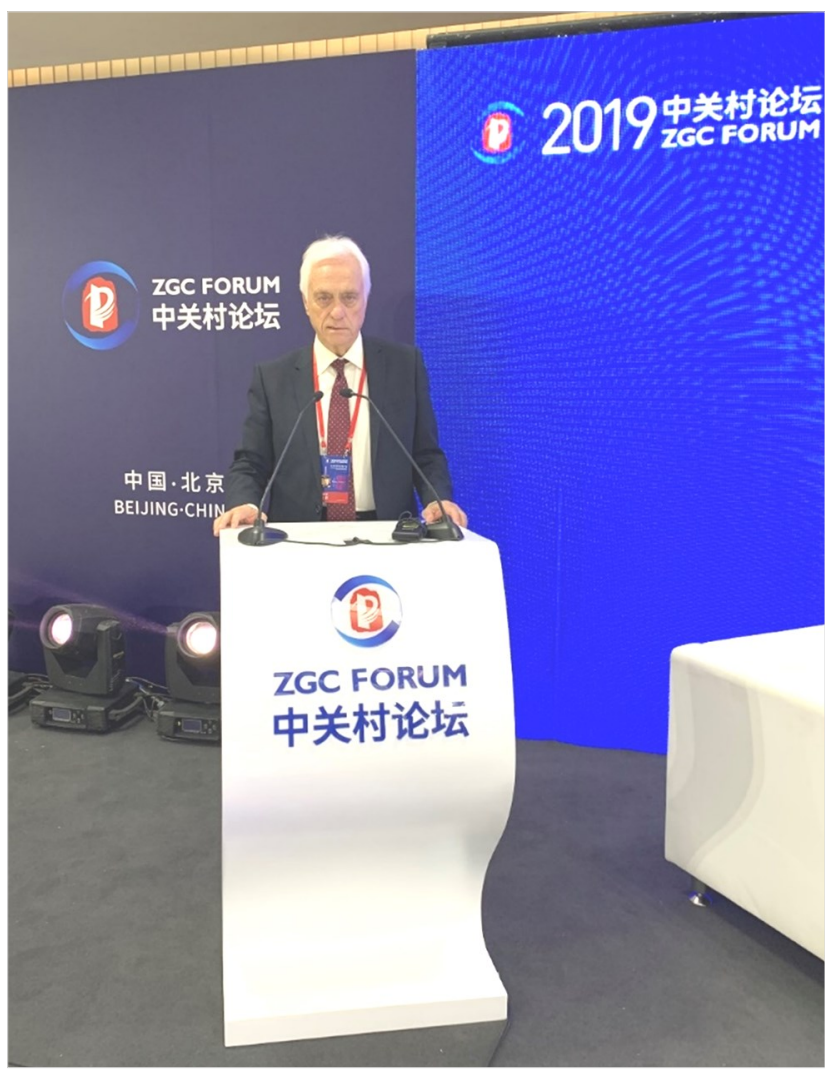

у 2019 р. Форум Чжунгуаньцунь відбувався в Пекіні 16-18 жовтня 2019 р. і був присвячений темі «Технології переднього краю та майбутнє розвитку індустрії». Форум організували спільно Міністерство науки і технологій КНР, Китайська академія наук та Китайська асоціація науки та технологій. Китайські державні і партійні лідери, керівники відповідних міністерств і комісій, а також відомі вчені, провідні підприємці, відомі інвестори та керівники міжнародних організацій з усього світу взяли участь в обміні досвідом та обговорили тенденції майбутнього розвитку світової науки та технологій, а також вивчення шляхів зміцнення міжнародного інноваційного співробітництва. Організаційний комітет Форуму Чжунгуаньцунь «Scientific and Technological 




Innovation and Cooperation by Global Academicians» запросив до участі В.Ю. Бикова, директора Інституту інформаційних технологій і засобів навчання Національної академії педагогічних наук України, доктора технічних наук, професора, дійсного члена НАПН України. Доповідь академіка НАПН України В.Ю. Бикова була присвячена концепції Інтернету речей і її реалізації у проєктах «Розумний дім».
Також В.Ю. Биков взяв участь ще в одному науковому заході - Всесвітньому саміті молодих учених у китайському м. Веньчжоу (26-27 жовтня 2019 р.), куди були запрошені лауреати Нобелівської премії та провідні вчені, які забезпечили захоплюючу наукову комунікацію 3 метою популяризації наукових знань, пропаганди наукових методів, поширення наукових ідей, просування духу науки та вдосконалення наукової грамотності громадян. На Саміті В.Ю. Биков поділився своїми інноваційними думками та баченням теми «Мій розумний дім». Всесвітній саміт молодих вчених створив п'ять платформ (секцій) для забезпечення тісної взаємодії між широкою громадськістю та провідними вченими світу (платформа № 1 - «Життя у відкритому світі»; платформа № 2 - «Великий вибух і наукові цикли»; платформа № 3 - «Шлях «Реакція Сузукі»; платформа № 3 - «Шлях «Реакція Сузукі»; платформа № 4 - «NMR-нова технологія декодування»; платформа № 5 - «Мій розумний дім» (проходила під керівництвом і за участі В.Ю. Бикова).

БИКОВ Валерій Юхимович

доктор технічних наук, професор, дійсний член НАПН України, директор Iнституту інформаційних технологій $і$ засобів навчання Національної академіі педагогічних наук України, м. Київ, Україна

\title{
ZGC FORUM 2019 "SCIENTIFIC AND TECHNOLOGICAL INNOVATION AND COOPERATION BY GLOBAL ACADEMICIANS"
}

October 16-18, 2019, Beijing, China

\author{
Valerii Bykov \\ DSc in Engineering, Professor, Full Member (Academician) of NAES of Ukraine, Director, Institute of Information \\ Technologies and Learning Tools of the National Academy of Educational Sciences of Ukraine, Kyiv, Ukraine
}

Abstract. A scientist from the National Academy of Educational Sciences of Ukraine was invited to make a presentation at the Zhongguancun International Forum "Scientific and Technological Innovation and Cooperation by Global Academicians", held in Beijing October 16-18, 2019. He was also invited to the World Summit of Young Scientists in Wenzhou, China (October 26-27, 2019), at which Valerii Bykov made a scientific report and was the head of the section.

Keywords: international forum; science center. 